medRxiv preprint doi: https://doi.org/10.1101/2020.11.22.20236422; this version posted November 24, 2020. The copyright holder for this preprint (which was not certified by peer review) is the author/funder, who has granted medRxiv a license to display the preprint in It is made available under a CC-BY-ND 4.0 International license.

\title{
The effectiveness of the three-tier system of local restrictions for control of COVID-19
}

Paul R Hunter ${ }^{1}$, Julii Brainard ${ }^{1}$, Alastair Grant ${ }^{2}$

${ }^{1}$ The Norwich Medical School, University of East Anglia, Norwich, NR4 7TJ, UK

${ }^{2}$ School of Environmental Science, University of East Anglia, Norwich, NR4 7TJ, UK

Corresponding author: Professor Paul Hunter Paul.Hunter@uea.ac.uk

\section{ORCID numbers}

Paul R. Hunter 0000-0002-5608-6144

Julii Brainard 0000-0002-5272-7995

Alastair Grant 0000-0002-1147-2375

\section{Declarations}

Conflict of interest

The authors declare that we have no conflict of interest.

\section{Funding}

Professor Hunter and Dr. Brainard were funded by the National Institute for Health Research Health Protection Research Unit (NIHR HPRU) in Emergency Preparedness and Response at King's College London in partnership with Public Health England (PHE) and collaboration with the University of East Anglia. The views expressed are those of the author(s) and not necessarily those of the NHS, the NIHR, UEA, the Department of Health or PHE. 
medRxiv preprint doi: https://doi.org/10.1101/2020.11.22.20236422; this version posted November 24,2020 . The copyright holder for this preprint (which was not certified by peer review) is the author/funder, who has granted medRxiv a license to display the preprint in It is made available under a CC-BY-ND 4.0 International license .

Despite it being over 10 months since COVID-19 was first reported to the world and it having caused over 1.3 million deaths it is still uncertain how the virus can be controlled whilst minimising the negative impacts on society and the economy. On the $14^{\text {th }}$ October, England introduced a three-tier system of regional restrictions in an attempt to control the epidemic. This lasted until the $5^{\text {th }}$ November when a new national lockdown was imposed. Tier 1 was the least and Tier 3 the most restrictive tiers. We used publicly available data of daily cases by local authority (local government areas) and estimated the reproductive rate ( $R$ value) of the epidemic over the previous 14 days at various time points after the imposition of the tier system or where local authorities were moved into higher tiers at time points after reallocation. At day 0 there vas very little difference in the $R$ value between authorities in the different groups but by day 14 the $R$ value in Tier 3 authorities had fallen to about 0.9 , in Tier 2 to about 1.0 and in Tier 1 the $R$ value was about 1.5. The restrictions in Tier 1 had little impact on transmission and allowed exponential growth in the large majority of authorities. By contrast the epidemic was declining in most Tier 3 authorities. In Tier 2, exponential growth was being seen in about half of authorities but declining in half. We concluded that the existing three tier system would have been sufficient to control the epidemic if all authorities had been moved out of Tier 1 into tier 2 and there had been more rapid identification and transfer of those authorities where the epidemic was increasing out of Tier 2 into Tier 3 . A more restrictive tier than Tier 3 may be needed but only by a small number of authorities.

Key words: COVID-19, social distancing, control measures 
medRxiv preprint doi: https://doi.org/10.1101/2020.11.22.20236422; this version posted November 24,2020 . The copyright holder for this preprint (which was not certified by peer review) is the author/funder, who has granted medRxiv a license to display the preprint in It is made available under a CC-BY-ND 4.0 International license .

\section{Introduction}

Since the end of 2019 the SARS-CoV-2 virus has spread globally and caused over 55 million cases and more than one million deaths from COVID-19. Several publications in recent months attempted to demonstrate what nonpharmaceutical interventions may or may not be successful in controlling the pandemic (Brauner et al. 2020, Hunter et al. 2020). There has also been debate as to the value of regional versus national control strategies. In October 2020 England introduced a three tier system for controlling COVID-19 (Prime Minister's Office 2020), with social mixing restrictions ranging from limits on maximum group sizes in Tier 1 through to a ban on household mixing indoors or in private gardens in Tier 3 . The system was meant to be flexible with all placements subject to ongoing review. Then on the 5th of November the English government imposed a national "lockdown" in which people were instructed to stay at home except for specific purposes; non-essential retail was closed, but schools and universities remained open (Department of Health and Social Care 2020). That a lockdown was about to be imposed was widely rumoured in news media prompting what appeared to be an unplanned announcement about the national lockdown about five days before it came into force (Blackall 2020). At the time of writing, the national lockdown in England is due to finish in on 2 December. It has been suggested that England will revert to a multi-tier control strategy similar to what was implemented in October. It would therefore be very valuable to understand whether or not the English three tier system was managing to control the epidemic prior to the imposition of the "lockdown". This paper presents a review of daily reported statistics of new infections by local authority in England and seeks to distinguish the transmissibility of COVID-19 depending on which tier local authorities had been placed.

\section{Methods}

All data on daily numbers of new cases of COVID-19 were downloaded from the English Department of Health and social care daily COVID dashboard. Daily data by local authority is maintained at https://coronavirus.data.gov.uk/details/about-data.

For each local authority, an estimate of the effective reproductive number (R) for preceding days was obtained by summing all reports of new COVID infections for each day and the previous six days. This was then compared with the sum of new cases over the previous seven-day period. $R$ was estimated using the equation given by Grant (2020) as

$$
R=\left(\frac{Y_{2}}{Y_{1}}\right)^{\frac{T}{j}}
$$

Where $Y_{1}$ and $Y_{2}$ are the numbers of cases in two consecutive weeks, $T$ is the generation time for the infection (here taken as 5 days) and $\mathrm{j}$ is the interval between the midpoints of the periods over which cases are counted (here 7 days). This estimator performs particularly well when R is close to 1 (Grant 2020).

In order to demonstrate the impact of the different tiers we estimated $\mathrm{R}$ values for all local authorities for days $0,7,14,21$ and 28 where day zero was the day that the three tier system was implemented (starting $14^{\text {th }}$ October). For those authorities that remained in Tier 1 throughout the four weeks the dates were the same. For local authorities that were in Tiers 2 or 3 on the $4^{\text {th }}$ November day 0 was not the $14^{\text {th }}$ October but rather the day that they were placed into their final tier and all subsequent dates taken from then. Local authorities that moved up a tier were not included in any analyses of their initial tier group. Instead any analyses from local authorities that started in one tier but moved into a higher tier were included for the lower tier up to 7 days after the reallocation of tier. Analyses in the newer higher tier were included as above. 
medRxiv preprint doi: https://doi.org/10.1101/2020.11.22.20236422; this version posted November 24,2020 . The copyright holder for this

preprint (which was not certified by peer review) is the author/funder, who has granted medRxiv a license to display the preprint in

It is made available under a CC-BY-ND 4.0 International license.

The mean and standard deviations of the $R$ values for each local authority were calculated in Microsoft Excel. The distribution of $\mathrm{R}$ values for local authorities in their final allocation is presented in box and whisker plots. Data from dates up to the $12^{\text {th }}$ of November were analysed, seven days after implementation of the national lockdown. COVID-19 has a median incubation period of about 5 days (Lauer et al. 2020), and test results tend to take 24-48 hours to return (Department of Health and Social Care 2020). Therefore, it was felt that data after 12 November, the restrictions associated with national lockdown rather than tiers would mostly influenced case counts. Comparison of the counts in different tiers was done using one way analysis of variance.

\section{Results}

Data were obtained on 315 local authorities. One local authority, High Peak (in East Midlands), was excluded from the analyses for Tier 2 because at the start only parts of High Peak were placed in Tier 2 to be followed days later by the remainder of the authority area.

Figure 1 shows the daily numbers of new cases reported in England based on the swab sample collection date. It can be seen that case numbers increased rapidly from early September through to 5 October, after which there was a less rapid increase till 16 October and then much slower increase from about the $23^{\text {rd }}$ to $30^{\text {th }}$ October, after which case numbers accelerated once more.

Table 1 shows the mean and standard deviation of the estimated $R$ for the authorities combined and disaggregated by allocated tier. It can be seen that for all included authorities, $R$ prior to the start of implementation was above 1.1, indicating exponential growth. As discussed above, the $R$ value was calculated giving an estimate over the previous 14 days. During the following four weeks the mean $\mathrm{R}$ value remained over 1.1. In Tier 1 the R values also remained fairly constant throughout the four weeks, indicating (at least in Tier 1 ) continued exponential growth. For Tier 2, on the date of implementation $\mathrm{R}$ was similar to that in Tier 1 . However, by day 14 the $\mathrm{R}$ value had fallen to about 1.0 , though on day 28 there was evidence that infection transmission had started increasing over the previous week. For Tier 3 authorities on day zero the $\mathrm{R}$ value was similar to the other tiers but by day $14, \mathrm{R}$ had fallen to about 0.9 where it remained. It can also be seen that as the $R$ value in those initial

Tier 1 authorities that were moved up to Tier 2 during the time period had higher $\mathrm{R}$ values than those Tier 1 authorities but that there was little difference between those Tier 2 authorities that remained in Tier 2 and those that were eventually moved up to Tier 3 prior to their move.

A one way analysis of variance comparing the mean $\mathrm{R}$ values in the Local Authorities in the three tiers showed no difference on day 0 but a very highly significant difference on days 7,14 and 21 , especially days 14 and 21 . On day 28 the difference was still significant but much less so, but this primarily reflects the relatively small number of authorities that could be included in day 28 . 
medRxiv preprint doi: https://doi.org/10.1101/2020.11.22.20236422; this version posted November 24, 2020. The copyright holder for this preprint (which was not certified by peer review) is the author/funder, who has granted medRxiv a license to display the preprint in

It is made available under a CC-BY-ND 4.0 International license .

Figure 1 Daily reports of new cases of COVID-19 in England based on sample collection date. ${ }^{\text {a }}$

Daily reports of new cases of COVID-19 in England

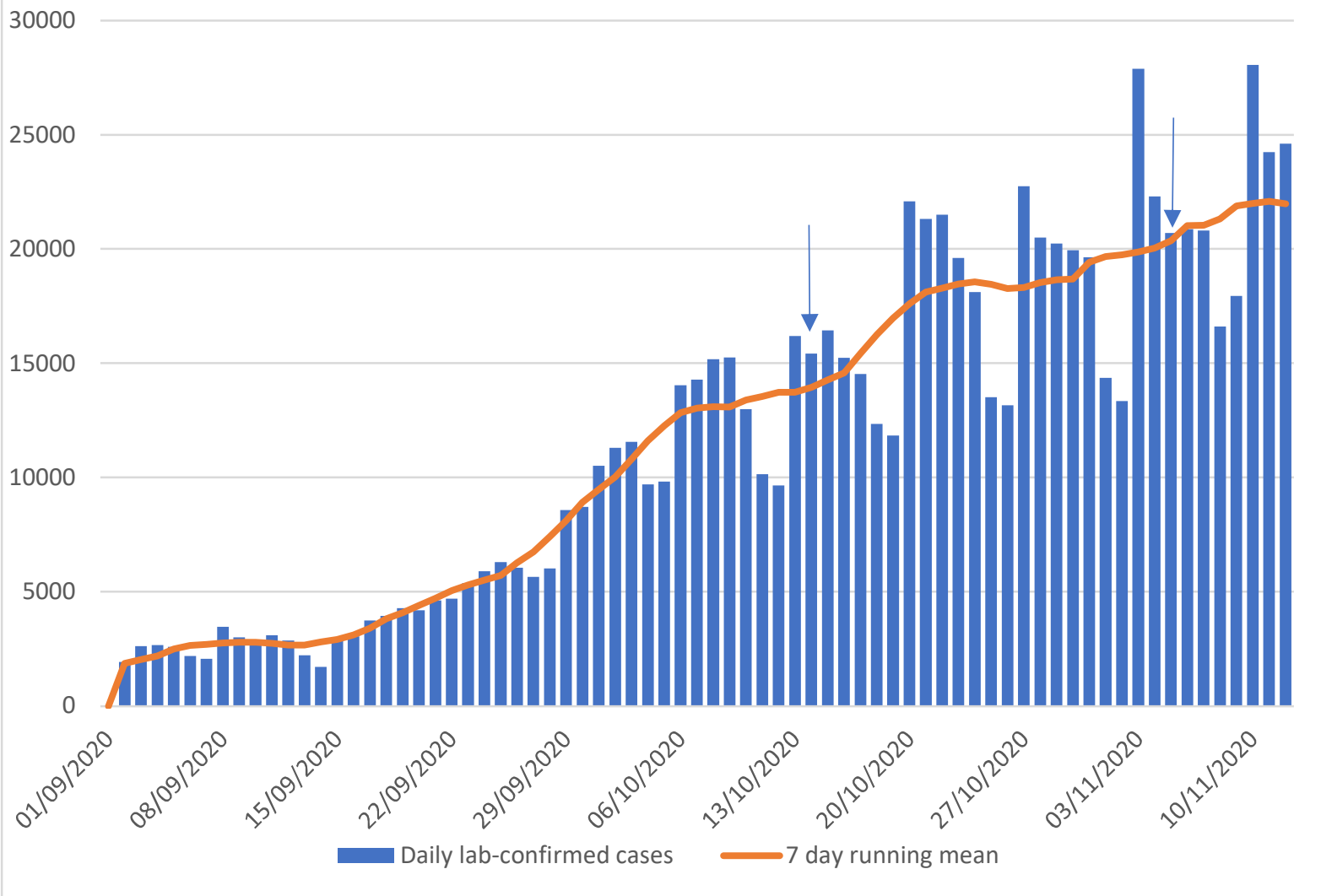

${ }^{\text {a }}$ Arrows indicate start of tier system on $14^{\text {th }}$ October and start of national lockdown on $5^{\text {th }}$ November 
medRxiv preprint doi: https://doi.org/10.1101/2020.11.22.20236422; this version posted November 24,2020 . The copyright holder for this preprint (which was not certified by peer review) is the author/funder, who has granted medRxiv a license to display the preprint in It is made available under a CC-BY-ND 4.0 International license .

Table 1. Summary statistics for the R values from each of the Local Authorities by tier

\begin{tabular}{|c|c|c|c|c|c|c|}
\hline & & \multicolumn{5}{|c|}{ Days after implementation } \\
\hline & & Day 0 & Day 7 & Day 14 & Day 21 & Day 28 \\
\hline \multirow[t]{3}{*}{ All local authorities } & Mean & 1.15 & 1.22 & 1.11 & 1.10 & 1.15 \\
\hline & Std Dev & 0.20 & 0.20 & 0.19 & 0.18 & 0.20 \\
\hline & $\mathrm{N}$ & 315 & 315 & 315 & 315 & 315 \\
\hline \multicolumn{7}{|l|}{ Authorities remaining in } \\
\hline \multirow[t]{3}{*}{ Tier 1 throughout } & Mean & 1.15 & 1.22 & 1.16 & 1.14 & 1.20 \\
\hline & Std Dev & 0.23 & 0.22 & 0.20 & 0.19 & 0.21 \\
\hline & $\mathrm{N}$ & 169 & 169 & 169 & 169 & 169 \\
\hline \multirow{4}{*}{$\begin{array}{l}\text { Authorities in Tier } 1 \text { prior } \\
\text { to moving into Tier } 2\end{array}$} & & & & & & \\
\hline & Mean & 1.18 & 1.36 & 1.21 & 1.18 & \\
\hline & Std Dev & 0.16 & 0.18 & 0.16 & 0.15 & \\
\hline & $\mathrm{N}$ & 76 & 26 & 26 & 22 & 0 \\
\hline \multicolumn{7}{|l|}{ Authorities in Tier 2 on } \\
\hline \multirow[t]{3}{*}{ 4th November } & Mean & 1.13 & 1.19 & 0.98 & 1.06 & 1.17 \\
\hline & Std Dev & 0.13 & 0.16 & 0.13 & 0.13 & 0.07 \\
\hline & $\mathrm{N}$ & 97 & 97 & 74 & 71 & 21 \\
\hline \multirow[t]{3}{*}{$\begin{array}{l}\text { Authorities in Tier } 2 \text { prior } \\
\text { to moving into Tier } 3\end{array}$} & Mean & 1.14 & 1.20 & 1.05 & 1.04 & \\
\hline & Std Dev & 0.18 & 0.17 & 0.09 & 0.10 & \\
\hline & $\mathrm{N}$ & 44 & 28 & 28 & 13 & 0 \\
\hline \multicolumn{7}{|l|}{ Authorities in Tier 3 on } \\
\hline \multirow[t]{3}{*}{ 4th November } & Mean & 1.13 & 1.04 & 0.89 & 0.92 & 0.94 \\
\hline & Std Dev & 0.15 & 0.12 & 0.07 & 0.09 & 0.09 \\
\hline & $\mathrm{N}$ & 48 & 47 & 34 & 19 & 6 \\
\hline \multirow[t]{2}{*}{$\begin{array}{l}\text { One way ANOVA } \\
\text { comparing R values } \\
\text { between Tiers } 1,2 \text { and } 3\end{array}$} & $\begin{array}{l}\mathrm{F} \\
\text { (variance } \\
\text { ratio) }\end{array}$ & 0.49 & 16.63 & 50.80 & 17.22 & 5.36 \\
\hline & $\mathrm{P}$ & 0.613 & $<0.00001$ & $<0.00001$ & $<0.00001$ & 0.005 \\
\hline
\end{tabular}

*Excluding High Peak from Tier 2 analyses as discussed in the text. 
medRxiv preprint doi: https://doi.org/10.1101/2020.11.22.20236422; this version posted November 24,2020 . The copyright holder for this preprint (which was not certified by peer review) is the author/funder, who has granted medRxiv a license to display the preprint in It is made available under a CC-BY-ND 4.0 International license .

Figure 2 shows the box and whisker plots for all authorities and for each of their final tiers. The large majority of local authorities in Tier 1 had $R$ values $>1$ and remained in exponential growth throughout the 28 days. By contrast, the majority of Tier 3 authorities had $R<1$ at least by Day 14 and so in these authorities the epidemic was in decline. Tier 2 shows an intermediate pattern, with about half of authorities continuing to see exponential growth on Day 14 while the remainder saw some decline, but the median value of $\mathrm{R}$ in Tier 2 authorities then increased on Days 21 and 28

\section{Discussion}

We undertook an analysis of new cases of COVID-19 by local authority in England from the 14th of October to the 12th of November. We demonstrated that the epidemic continued to grow in most areas during this time. We further showed that the rate of growth of the epidemic could largely be predicted by which tier a local authority was placed in. In Tier 1, the least restricted tier, the large majority of authorities continued to see exponential growth. This is in contrast to Tier 3, where most authorities saw a decline in cases during the same time and a there was a reduction in the $R$ values to less than 1 . Analysis of Tier 2 authorities found that that overall case numbers remained static after the first week or so. Roughly half of the authorities in Tier 2 continued to see some growth and the other half had decline. Of note is that for Tier 2 there was little difference in the $R$ value between authorities that were moved from Tier 2 into 3 and those that remained in Tier 2 . This may suggest that the how rapidly a local epidemic was growing had little effect on the decision about whether authorities were placed in Tiers 2 or 3.

This is a retrospective observational study and, as such is subject to potential confounding. However, we are not aware of events that could have affect the epidemic other than which tier the local authority had been placed in. The data from day 28 slightly overlap with the national lockdown period which started 5 th of November. However, it is unlikely that in the first 7 days of the national lockdown there would have been much impact on case numbers given the time to incubate the disease and then obtain a test result. On the other hand, case numbers were noted to increase more rapidly in early November than they did in the last week of October. It has been suggested that this increase in cases in the early November may have been due to increased socialisation after the national lockdown was announced and before it was implemented. At present, this has yet to be proven. We did note some increases in R values at day 28 in all tiers so need to be cautious about interpreting the impact of the tier system at that time point.

Whilst our analysis shows a clear difference in $\mathrm{R}$ values between local authorities depending on which tier they are in, it cannot be determined from our analysis what aspects of the restrictions in Tiers 1-3 were responsible for case count outcomes. In the UK, Bernal et al. (2020) reported that secondary transmission within households is one of the most important risk factors for acquiring the infection. Nevertheless, banning gatherings of groups of people have been shown to be associated with reduced transmission even when restricting gatherings to less than 10 (Brauner et al. 2020, Hunter et al. 2020; Li et al, 2020; Cevik et al. 2020). One of the main characteristics of the English Tier system was in fact to reduce the opportunities for groups of people to gather indoors in any number. It is believed that "superspreaders" who infect large numbers of other individuals, are crucial to the continued spread of the virus (Althouse et al. 2020) and it is likely that superspreading events would also have been less like given the reduced opportunities for gatherings with the higher English Tiers. 
medRxiv preprint doi: https://doi.org/10.1101/2020.11.22.20236422; this version posted November 24, 2020. The copyright holder for this preprint (which was not certified by peer review) is the author/funder, who has granted medRxiv a license to display the preprint in

perpetuity.
It is made available under a CC-BY-ND 4.0 International license .

Figure 2 Box and Whisker plots of distribution of estimated of R values by days after implementation of the tier system or for Tiers 2 and 3 by days after movement into these final tiers by local authority combined and in different tiers based on final tier allocation on $4^{\text {th }}$ November.
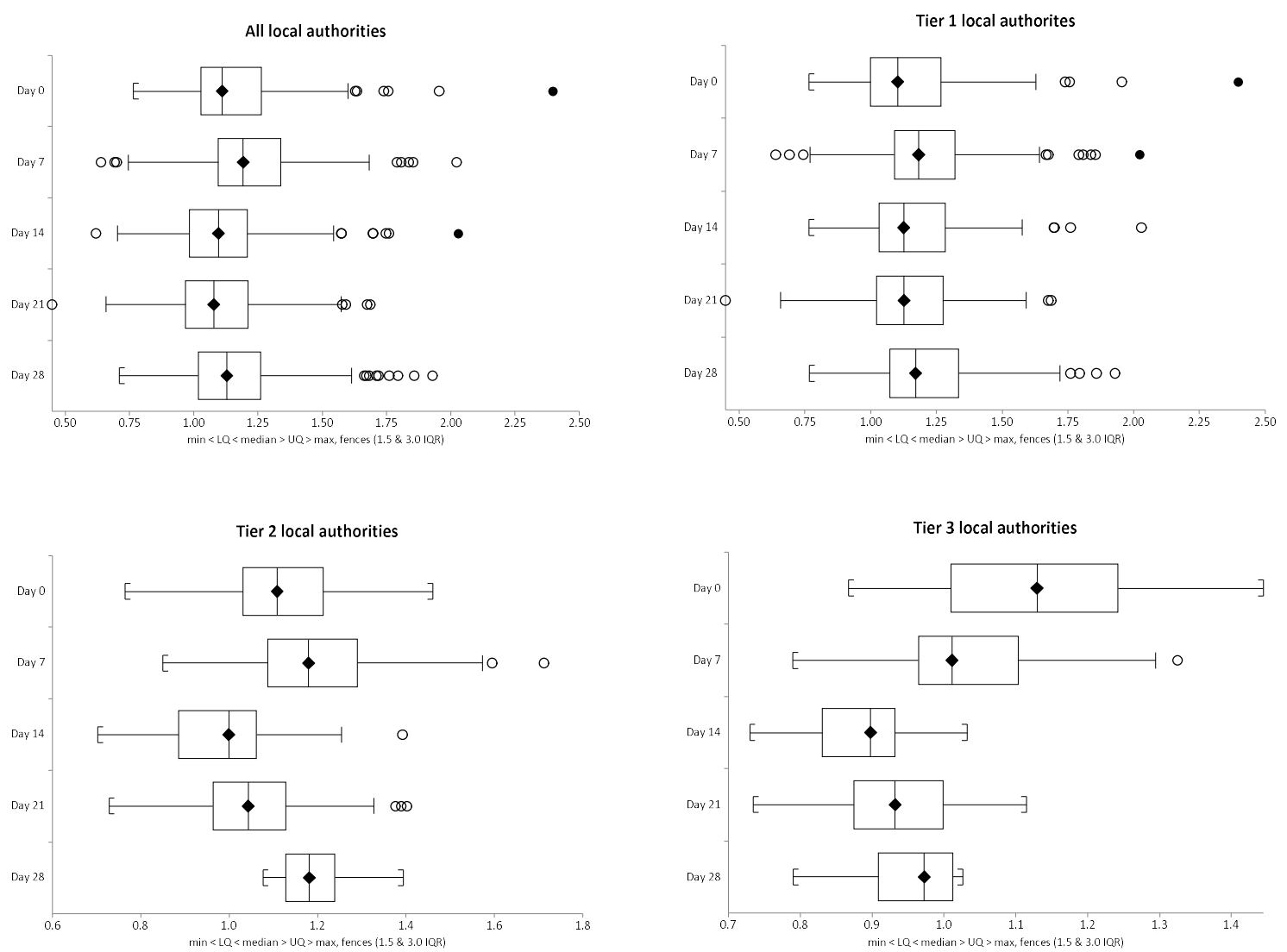
medRxiv preprint doi: https://doi.org/10.1101/2020.11.22.20236422; this version posted November 24,2020 . The copyright holder for this preprint (which was not certified by peer review) is the author/funder, who has granted medRxiv a license to display the preprint in It is made available under a CC-BY-ND 4.0 International license .

In general, higher tiers allowed less social interaction between people from different households, especially in enclosed environments. For instance, Tier 1 allowed for groups of maximum six persons from different households to meet indoors or outdoors. Tier 2 permitted such groups to meet only outdoors up to six people. In Tier 3 people were not allowed to socialise with anyone they did not live with indoors or outdoors in private gardens or most outdoor hospitality venues unless they were part of mutual support 'bubbles'. Groups of up to six were allowed to meet in outdoor public spaces such as parks. There were corresponding increased social mixing restrictions described by the Tier system with respect to many other activities, such as sport, rules while visiting restaurants, travel outside home area, etc. Consequently our findings are consistent with what would be expected from previous studies (Brauner et al. 2020, Hunter et al. 2020; Li et al, 2020; Cevik et al. 2020).

In conclusion, we have shown that the tier system probably was helping to reduce transmission of the epidemic in England. However, case numbers were continuing to increase albeit more slowly than previously. Placement in Tier 1 was clearly inadequate to control spread for most authorities, while Tier 3 was highly effective in the great majority of local authorities. In around half of the local authorities in Tier 2 were still seeing exponential growth.

It seems likely that the tier system will better prevent spread of SARS-CoV-2 with faster identification of the appropriate placement of each local authority and swifter reallocation when needed. Our findings would suggest that about half of authorities originally placed in Tier 2 would more appropriately have been placed in tier 3 and almost all of the authorities originally placed in Tier 1 should have been placed in Tier 2 . It has yet to be decided how England will move forward when the current national lockdown comes to an end. Whilst an additional even more restrictive tier may be needed, the evidence from Tier 3 areas so far suggests that Tier 3 restrictions are likely to adequate for most but not necessarily all local authority areas. What is needed as we move out of the national lockdown is a faster mechanism to identify those areas where the epidemic is not being controlled that can enable more-timely placement into a more appropriate tier. However, the extent to which there is social acceptance of, and compliance with, restrictions is at least as important as the level of restrictions that are nominally in force (Bellato 2020). Self-reported compliance with many of the social contact rules implemented to prevent virus spread most of the time has been fairly good, but not perfect in the UK (Bellato, 2020; Office for National Statistics 2020). However, there is evidence of widespread confusion about social distancing regulations and when a SARS-CoV-2 test is appropriate, impacting on people's ability to comply with them (Office for National Statistics 2020; Williams et al 2020; Smith et al 2020). No formal set of guidelines and restrictions will be effective unless the general public understand and support the restrictions and control strategy.

\section{References}

Bellato A (2020). Psychological factors underlying adherence to COVID-19 regulations: A commentary on how to promote compliance through mass media and limit the risk of a second wave. Social Sciences \& Humanities Open. 2020 Jan 1;2(1):100062.

Bernal JL, Panagiotopoulos N, Byers C, Vilaplana TG, Boddington NL, Zhang X, Charlett A, Elgohari S, Coughlan L, Whillock R, Logan S. Transmission dynamics of COVID-19 in household and community settings in the United Kingdom. medRxiv.

https://www.medrxiv.org/content/10.1101/2020.08.19.20177188v1.full.pdf 
medRxiv preprint doi: https://doi.org/10.1101/2020.11.22.20236422; this version posted November 24,2020 . The copyright holder for this preprint (which was not certified by peer review) is the author/funder, who has granted medRxiv a license to display the preprint in It is made available under a CC-BY-ND 4.0 International license .

Brauner, J. M., M. Sharma, S. Mindermann, A. B. Stephenson, T. Gavenčiak, D. Johnston, J. Salvatier, G. Leech, T. Besiroglu and G. Altman (2020). "The effectiveness and perceived burden of nonpharmaceutical interventions against COVID-19 transmission: a modelling study with 41 countries." medRxiv.

Cevik M, Marcus JL, Buckee C, Smith TC (2020) SARS-CoV-2 transmission dynamics should inform policy Clin Infect Dis. doi: $\underline{10.1093 / \mathrm{cid} / \mathrm{ciaa} 1442}$

Department of Health and Social Care (2020a) New national restrictions from 5 November https://www.gov.uk/guidance/new-national-restrictions-from-5-november

Grant A. (2020) The reproduction number R for COVID-19 in England: Why hasn't "lockdown "been more effective?. medRxiv. https://www.medrxiv.org/content/10.1101/2020.07.02.20144840v1

Hunter, P. R., F. Colon-Gonzalez, J. S. Brainard and S. Rushton (2020). "Impact of non-pharmaceutical interventions against COVID-19 in Europe: a quasi-experimental study." medRxiv.

Li Y, Campbell H, Kulkarni D, Harpur A, Nundy M, Wang X, Nair H, for COVID UN (2020). The temporal association of introducing and lifting non-pharmaceutical interventions with the time-varying reproduction number (R) of SARS-CoV-2: a modelling study across 131 countries. The Lancet Infectious Diseases.

Office for National Statistics (2020) Coronavirus and the social impacts on Great Britain: 20 November 2020 https://www.ons.gov.uk/peoplepopulationandcommunity/healthandsocialcare/healthandwellbeing/bulleti ns/coronavirusandthesocialimpactsongreatbritain/20november 2020

Prime Minister's Office (2020). Prime Minister announces new local COVID Alert Levels. 2020.

Smith LE, Potts HW, Amlot R, Fear NT, Michie S, Rubin J. (2020) Adherence to the test, trace and isolate system: results from a time series of 21 nationally representative surveys in the UK (the COVID-19 Rapid Survey of Adherence to Interventions and Responses [CORSAIR] study). medRxiv.

Williams SN, Armitage CJ, Tampe T, Dienes K. (2020) Public perceptions of non-adherence to COVID-19 measures by self and others in the United Kingdom. medRxiv. 